\title{
Proceeding
}

Supplementary Issue: Winter Conferences of Sports Science. International Conference of Engineering, Innovation Technology and Applied Science.

\section{An assessment of standard regulatory framework for Islamic Banking System in Bangladesh}

\author{
SHAFIQUL HASSAN \\ Prince Sultan University, Riyadh, Saudi Arabia
}

\begin{abstract}
Regulatory framework for Islamic banking system has been theoretically explored in the existing literature in different parts of Muslim countries including Bangladesh. Islamic banking has been growing in Bangladesh since few decades ago. Scholarly researches have investigated different theoretic bases for the operation of Islamic baking in the country. However, theoretical assumptions are no longer viable or sufficient in establishing standard regulatory framework for Islamic banking system in predominant Muslim countries. This paper primarily aims at assessing Quantitative research method was employed. The population comprised promoters of Islamic banking. As regards to sample, the researcher used convenient sampling technique in distributing 180 survey questionnaires online to the promoters of Islamic banking system in Bangladesh in order to collect data for this research. Descriptive statistics by using frequencies, percentage, means and standard deviations were used via Statistical Package for Social Science (SPSS) version 16.0 for data analysis. Three factors of standard regulatory framework (SRF) (i.e. Operation of Islamic banking (OIB), Bank Control Law (BCL); Profit-Loss Sharing (PLS) were assessed in this study. The findings showed that the majority of the respondents strongly agreed with underlining indicators (i.e. OIB, BCL and PLS) of standard regulatory framework in the context of Bangladesh. In conclusion, the three identified factors of regulatory framework could complement the existing regulations in Bangladesh. It is therefore recommended that the country should expand the scope of regulatory framework by exploring the regulatory framework being provided in countries like Saudi Arabia and Malaysia in order to effectively standardise it in the country.

Keywords: Regulatory framework; Operation of Islamic banking (OIB); Bank Control Law (BCL); Profit-Loss Sharing (PLS).

\section{Cite this article as:}

Hassan, S. (2020). An assessment of standard regulatory framework for Islamic Banking System in Bangladesh. Journal of Human Sport and Exercise, 15(2proc), S462-S470. doi:https://doi.org/10.14198/jhse.2020.15.Proc2.37

Corresponding author. Prince Sultan University, Riyadh, Saudi Arabia.

E-mail: shassan@psu.edu.sa

Supplementary Issue: Winter Conferences of Sports Science. International Conference of Engineering, Innovation Technology and Applied Science.

JOURNAL OF HUMAN SPORT \& EXERCISE ISSN 1988-5202

(C) Faculty of Education. University of Alicante

doi:10.14198/jhse.2020.15.Proc2.37
\end{abstract}




\section{INTRODUCTION}

The conceptual idea of Islamic banking and finance was traceable to Egypt and Malaysia in the 1960s. Indeed, literature posits the first Islamic bank was founded in Egypt while the first Shariah-compliant fund was founded in Malaysia in 1963 respectively (Mondher, 2013). The role of Islamic Development Bank (IDB) founded in 1975 could not be under-estimated in providing regulation and supervision for the operation of Islamic banking and finance. For instance, Auditing organization for Islamic Financial Institutions (AOIFI) was founded in Bahrain mainly to serve as self-regulation for Islamic banking and finance industry (Obaidullah, 2005). Similarly, Islamic Finance Service Board (IFSB) was founded in 2000 to serve as regulatory agency for Islamic banking and finance with the sole objective of fostering transparency and regulation for Islamic financial services.

However, the evolvement of Islamic banking in different parts of Muslim world gives room for addressing peculiar challenges in Muslim countries. Recently, the promoters of Islamic banking and finance have seen the need to expand the scope of Islamic banking specifically in providing regulatory framework (Obaidullah, 2005; Mondher, 2013). As a result, regulatory framework of Bangladesh aimed at comparatively investigated is presented in the subsequently sub-headings (Godino et al., 2019).

Furthermore, Bangladesh Government has been making effort to expand the activities of banking sector. Indeed, 1972 marked the beginning of this development as an attempt to enhance socioeconomic activities in the country. Similarly, the government policy allowed private sector to establish commercial and investment banks. Currently, literature identifies that out of total 51 banks in the country, there are six Islamic banks in the country namely: Al-Arafah Islamic Bank Limited, Al-Baraka Bank Bangladesh Limited, Islamic Bank Bangladesh Limited, Shahjalal Bank Limited Social Investment Bank Limited and Shamil Bank of Bahrain as literature contends (Ahmad and Kabir, 2007). It should be reiterated that, Shamil Bank of Bahrain being the largest Islamic bank in the entire world had its branch in Bangladesh in 1998. Hence, it is essential to explore the three indicators of regulatory framework in Bangladesh namely: Operation of Islamic banking (OIB), Bank Control Law (BCL); Profit-Loss Sharing (PLS). Each of these is explained in the subsequent paragraphs.

First, pertaining to the Operation of Islamic Banking (IOB), literature such as Ahmad (2004) posits that, in spite of several efforts to standardize Islamic banking system in Bangladesh, there is no independent Islamic Banking Act that specifically regulates and supervises the activities of Islamic banking. As a result, Central Bank of Bangladesh (CBB) uses the same regulations meant for conventional banks over Islamic bank whereby the goals of conventional banks are different from Islamic banks. It is thereby essential that there is need for the establishment of separate unit handling the activities of Islamic banks which is expected to be Sharī'ah-compliant.

Second, regarding the Bank Control Law (BCL), the Central Bank of Bangladesh (CBB) plays significant role pertaining to the regulation of banking sector in the country where there are different regulations being put in place such as: the Bangladesh Bank Order 1972, the Income Tax Ordinance 1984, the Bank Companies Act 1991 and the Securities and Exchange Commission Act 1993 (2006). All these are considered as regulatory frameworks for the operation of banking system including Islamic banks- in the context of Bangladesh (Ahmad, 2004). It should be stressed that in Bangladesh, there is a difference between conventional banks and Islamic banks in terms of Statutory Liquidity Requirement (SLR) whereby the requirement for conventional banks is $20 \%$ and $10 \%$ is the requirement for Islamic banks as literature expounds (Ahmed, 1999: Issaliyeva et al, 2018). 
Third, Profit-Loss Sharing (PLS) in an integral part of operation of Islamic banks in different parts of Muslim countries. Thus, the government allows the Islamic banks to comply with Shari'ah principles specifically by permitting the Islamic banks to use their discretion to fix their profit and loss sharing (PLS) ratios under indirect monetary policy (Ahmad, 2006). However, literature identifies problems of Islamic banking in Bangladesh (Archer and Karim, 2009; Ahmad, 2001). Nonetheless, supervisory and regulatory roles of capital adequacy is essential for profit-sharing investment as literature expounds (Archer, Karim, and Sundararajan, 2010). Based on the foregoing explication, this paper primarily assesses the three components of regulatory framework for Islamic banks in Bangladesh.

\section{METHODOLOGY}

The methodology used in this paper is survey research design. Different aspects are presented as follows: instrument, validity and reliability, population and sample, data collection and data analysis. Each of these is explained in the subsequent sub-headings.

\section{Instrument}

Survey questionnaire was employed as instrument of this paper. The instrument was self-designed specifically emanated from the existing studies (Archer \& Karim, 2009; Archer, Karim \& Sundarajan, 2010). In addition, a 5-point Likert scale namely: 1 = strongly disagree (SD); 2 = disagree (D); 3 = undecided (UN); $4=$ agree $(\mathrm{A})$ and $5=$ strongly agree $(\mathrm{SA})$ was used. The use of variation of Likert scale allows different variations of responses from the respondents as. The questionnaire covers different components of regulatory framework of Islamic banking and finance which are: Operation of Islamic banking (OIB), Bank Control Law (BCL); Profit-Loss Sharing (PLS). Five (5) items were used to measure each component. Hence, the total number of items contained in the questionnaire were fifteen (15) items.

\section{Validity and reliability of instrument}

On one hand, Pertaining to validity of the instrument, in one hand, the items were worded to reflect simplicity, flexibility and understandability by the respondents among the promoters of Islamic banking and finance in selected three countries of predominant countries. On the other hand, content validity was carried out to address the ambiguities of the items contained in the instrument. In order to ensure that content validity was done accurately, conceptual framework of the study was developed from extant literature (Ahmad, 2007; Archer, Karim \& Sundararajan, 2010). Out of initial 20 items that were developed, only six (6) items were not relevant according to the suggestions of two experts in Islamic banking and finance. Then, according to the suggestions given by the experts, and consequently deleted. Similarly, some statements were suggested to be rephrased in order to make them clear and flexible to the respondents.

\section{Population and sample}

The population of this study comprised all promoters of Islamic banking system in both public and private sectors in Bangladesh. However, convenient and purposeful sampling technique was used to select the total of 180 respondents among the citizens of Bangladesh via online. The entire country has majority Muslim population and it is also in forefront in promoting Islamic banking system.

\section{Data collection and data analysis}

On one hand, regarding data collection, the instrument was administered online to the promoters of Islamic banking in Bangladesh. In other word, the instrument (questionnaire) was distributed among promoters of Islamic banking and finance in the country. Hence, the respondents were requested to show their agreement or disagreement to various items embodied in the survey questionnaire. Indeed, the researcher strictly 
monitored the filling of the questionnaire via online. In return, after responding to the questionnaire among the promoters of Islamic banking, out of 180 questionnaires that were targeted by the researcher, all incomplete questionnaires of 11 were discarded; thus 169 questionnaires were used for the final analysis of this research.

On the other hand, concerning the analysis of the study, statistical package for social science (SPSS) version 16.0 was employed for the data analysis. Descriptive Statistics with computation of frequencies, percentages, means and standard deviations were used to know the opinions of the promoters of Islamic banking in Bangladesh with respect to the predictors of standard regulatory framework of Islamic banking and finance. The subsequent sub-headings present the analysis of the findings of the paper. As a result, the targeted sample size is adequate for the use of chosen statistical analysis.

\section{RESULTS}

The subsequent explanations present the results on various factors of standard framework for Islamic banking in Bangladesh. The conceptualized variables are: Operation of Islamic banking (OIB), Bank Control Law (BCL); Profit-Loss Sharing (PLS); Results on each factor are consequently presented.

\section{Results on operation of Islamic Banking (OIB)}

This section presents the data on Operation of Islamic Banking (OIB), descriptive statistics by computing frequencies and percentages, means and standard deviation were used.

The majority of the respondents (134 or $79.3 \%$ ) agreed that the Islamic banks have no provision to charge any extra money from the defaulters. Nonetheless, $12(7.1 \%)$ disagreed. However, a few numbers of the respondents $(23$ or $13.6 \%)$ were neutral $(M=4.23 ; \mathrm{STD}=0.93)$.

In addition, it was asserted by the majority of the respondents (146 or $86.4 \%$ ) agreed that the Islamic bank gives due importance to the public interest in different Muslim countries. ( $M=4.25$; $S T D=1.63)$; $13(7.7 \%)$ disagreed and on this statement while $10(5.9 \%)$ maintained neutrality.

More so, pertaining to the respondents' perceptions on the participation in partnership business as the fundamental function of the Islamic banks, the majority of the sampled respondents (141 or $83.4 \%$ ) agreed on this $(M=5.81$; STD $=7.39)$. Nevertheless, $9(5.4 \%)$ disagreed on this statement and only $19(11.2 \%)$ were natural.

Furthermore, the majority of the respondents (156 or $92.3 \%$ ) agreed that in the modern Islamic banking system, it has become one of the service- oriented functions of the Islamic banks to collect and distribute zakah $(\mathrm{M}=4.47$; STD $=0.69)$. Nonetheless, 3 or $1.8 \%$ disagreed with the statement while only $10(5.9 \%)$ were neutral.

Regarding the scope of Islamic bank's activities is wider when compared with a conventional bank. It is, in effect, a multipurpose institution, the whole sample ( 173 or $81.3 \%$ ) agreed with the statement ( $M=5.31$; STD $=7.48)$; however, $13(8.7 \%)$ disagreed with the statement, however, only $19(11.2 \%)$ were neutral. Table 1 shows the responses of the respondents pertaining to the operation of Islamic banking (OIB) in Bangladesh. 
Table 1. Perceptions of the respondents on the Operation of Islamic Banking.

\begin{tabular}{|c|l|c|c|c|c|c|}
\hline S/N & Items & $\mathbf{A}$ & $\mathbf{N}$ & $\mathbf{D}$ & $\mathbf{M}$ & $\mathbf{S D}$ \\
\hline 1. & $\begin{array}{l}\text { The Islamic banks have no provision to charge any } \\
\text { extra money from the defaulters. }\end{array}$ & $\begin{array}{c}134 \\
(79.3 \%)\end{array}$ & $\begin{array}{c}23 \\
(13.6 \%)\end{array}$ & $\begin{array}{c}12 \\
(7.1 \%)\end{array}$ & 4.23 & 0.93 \\
\hline 2. & $\begin{array}{l}\text { The Islamic bank gives due importance to the public } \\
\text { interest. }\end{array}$ & $\begin{array}{c}146 \\
(86.4 \%)\end{array}$ & $\begin{array}{c}10 \\
(5.9 \%)\end{array}$ & $\begin{array}{c}13 \\
(7.7 \%)\end{array}$ & 4.25 & 1.06 \\
\hline 3. & $\begin{array}{l}\text { Participation in partnership business is the fundamental } \\
\text { function of the Islamic banks. }\end{array}$ & $\begin{array}{c}141 \\
(83.4 \%)\end{array}$ & $\begin{array}{c}19 \\
(11.2 \%)\end{array}$ & $\begin{array}{c}9 \\
(5.4 \%)\end{array}$ & 5.81 & 7.39 \\
\hline 4. & $\begin{array}{l}\text { In the modern Islamic banking system, it has become } \\
\text { one of the service- oriented functions of the Islamic } \\
\text { banks to collect and distribute zakah. }\end{array}$ & $\begin{array}{c}156 \\
(92.3 \%)\end{array}$ & $\begin{array}{c}10 \\
(5.9 \%)\end{array}$ & $\begin{array}{c}3 \\
(1.8 \%)\end{array}$ & 4.47 & 0.69 \\
\hline 5. & $\begin{array}{l}\text { The scope of Islamic bank's activities is wider when } \\
\text { compared with a conventional bank. It is, in effect, a } \\
\text { multipurpose institution. }\end{array}$ & $\begin{array}{c}137 \\
(81.3 \%)\end{array}$ & $\begin{array}{c}19 \\
(11.2 \%)\end{array}$ & $\begin{array}{c}13 \\
(8.7 \%)\end{array}$ & 5.31 & 7.48 \\
\hline
\end{tabular}

\section{Results on Bank Control Law (BCL)}

This part attempts to present the responses of the respondents pertaining to the Bank Control Law $(B C L)$ in the selected three countries (Bangladesh, Malaysia and Saudi Arabia. Descriptive statistics by computing frequencies and percentages, means and standard deviation were used.

The majority of the respondents (166 or $98.2 \%$ ) agreed that the Islamic Banking Act specifically regulates and supervises the activities of Islamic banking ( $M=4.24$; STD $=0.54) ; 36(1.8 \%)$ disagreed with the statement.

In addition, the sampled respondents (166 or $98.3 \%$ ) agreed that the central bank uses the same regulations meant for conventional banks over Islamic bank while just only 3 (1.8) disagreed with the statement ( $M=$ $4.42 ;$ STD $=0.59$ ).

The majority of the respondents (160 or $94.6 \%$ ) agreed that the goals of conventional banks are different from Islamic banks as shown in the banks' regulations. However, $6(3.6 \%)$ maintained neutrality on this. However, $3(1.8 \%)$ disagreed with the statement $(M=4.03 ; S T D=0.56)$.

Table 2. Respondents' perceptions on Bank Control Law (BCL).

\begin{tabular}{|c|c|c|c|c|c|c|}
\hline$S / N$ & Items & A & $\mathbf{N}$ & D & $M$ & SD \\
\hline 1. & $\begin{array}{l}\text { Islamic Banking Act specifically regulates and } \\
\text { supervises the activities of Islamic banking. }\end{array}$ & $\begin{array}{c}166 \\
(88.2 \%)\end{array}$ & - & $\begin{array}{c}3 \\
(1.8 \%) \\
\end{array}$ & 4.24 & 0.54 \\
\hline 2. & $\begin{array}{l}\text { The central bank uses the same regulations meant for } \\
\text { conventional banks over Islamic bank. }\end{array}$ & $\begin{array}{c}166 \\
(98.3 \%)\end{array}$ & - & $\begin{array}{c}3 \\
(1.8 \%)\end{array}$ & 4.42 & 0.59 \\
\hline 3. & $\begin{array}{l}\text { The goals of conventional banks are different from } \\
\text { Islamic banks. }\end{array}$ & $\begin{array}{c}160 \\
(94.8 \%)\end{array}$ & $\begin{array}{c}6 \\
(3.6 \%)\end{array}$ & $\begin{array}{c}3 \\
(1.8 \%)\end{array}$ & 4.03 & 0.56 \\
\hline 4. & $\begin{array}{l}\text { There is an independent department handling the } \\
\text { activities of Islamic banks which is Shar' 'ah-compliant. }\end{array}$ & $\begin{array}{c}160 \\
(94.6 \%)\end{array}$ & $\begin{array}{c}6 \\
(3.6 \%) \\
\end{array}$ & $\begin{array}{c}3 \\
(1.8 \%)\end{array}$ & 4.21 & 0.74 \\
\hline 5. & $\begin{array}{l}\text { There are areas of agreement in terms of transactions } \\
\text { between Islamic banks and conventional banks with } \\
\text { respect to profit-loss sharing. }\end{array}$ & $\begin{array}{c}156 \\
(92.3 \%)\end{array}$ & $\begin{array}{c}10 \\
(5.9 \%)\end{array}$ & $\begin{array}{c}3 \\
(1.8)\end{array}$ & 4.33 & 0.67 \\
\hline
\end{tabular}


Onwards, the sampled respondents (142 or $84.1 \%$ ) agreed that there is an independent department handling the activities of Islamic banks which is Shari 'ah-compliant. ( $M=4.21$; STD $=0.74) ; 24$ or $14.2 \%$ were neutral with the statement.

In addition, the sampled respondents (156 or $92.3 \%$ ) agreed that, there is regulation on both Islamic capital market and Takaful sector. On the other hand, $10(5.9 \%)$ disagreed with the statement (M = 4.33; STD = 0.67). Table 2 shows the responses of the respondents pertaining to the Bank Control Law (BCL) in Bangladesh.

\section{Results on Profit-Loss Sharing (PLS)}

In this section, an attempt is made to present analysis on Profit-Loss Sharing (PLS) as being operated by Islamic banks which was expressed by the opinions of promoters of Islamic banking. Thus, descriptive statistics by computing frequencies and percentages, means and standard deviation are employed. Profitloss sharing is an important indicator standard framework of Islamic banking.

The sampled respondents (115 or $168.0 \%$ ) agreed that Islamic banks have discretion to fix their profit and loss sharing (PLS) ratios under indirect monetary policy; 21 (12.4\%) disagreed with the statement while 33 or $19.5 \%$ were neutral with the statement $(M=3.69 ; S T D=1.02)$.

It was perceived by the majority of the respondents (151 or $89.4 \%$ ) that there is need for guidelines on for the disclosure of reports and financial statements of Islamic Banks. However, 6 (3.6\%) disagreed with this while $12(7.1 \%)$ maintained neutrality with the statement $(M=4.21 ; S T D=0.79)$.

Moreover, the respondents (145 or $85.8 \%$ ) agreed that Shariah Board or Shar'iah Advisory Council should play a significant role in determining profit-loss sharing. $(M=4.42$; $S T D=0.93) ; 10(5.9 \%)$ disagreed on this while $14(8.3 \%)$ were neural.

Table 3. Perceptions of the respondents on the Profit-Loss Sharing (PLS).

\begin{tabular}{|c|c|c|c|c|c|c|}
\hline $\mathbf{B N}$ & $\mathrm{ems}$ & A & $\mathbf{N}$ & D & $M$ & SD \\
\hline 1. & $\begin{array}{l}\text { fit and loss } \\
\text { ry policy. }\end{array}$ & $\begin{array}{c}115 \\
(16.0 \%)\end{array}$ & $\begin{array}{c}33 \\
(19.5 \%) \\
\end{array}$ & \begin{tabular}{|c|}
21 \\
$(13.4 \%)$ \\
\end{tabular} & 3.69 & 1.02 \\
\hline 2. & ore is nod for ouidaling on for th & $\begin{array}{l}97 \\
26.1 \%)\end{array}$ & $\begin{array}{c}32 \\
(13.7 \%)\end{array}$ & $\begin{array}{c}242 \\
(65.3 \%) \\
\end{array}$ & 4.21 & 0.79 \\
\hline 3. & $\begin{array}{l}\text { r'iah Board or Shar'iah Advisory Council should } \\
\text { a significant role in determining profit-loss } \\
\text { ring. }\end{array}$ & $\begin{array}{c}83 \\
(22.4 \%)\end{array}$ & $\begin{array}{c}47 \\
(12.7 \%)\end{array}$ & $\begin{array}{c}241 \\
(65 \%)\end{array}$ & 4.42 & 0.93 \\
\hline 4. & $\begin{array}{l}\text { Islamic banks based profit-loss sharing on joint } \\
\text { business partnerships not on utilization of loan for } \\
\text { financing the business of their customers like } \\
\text { conventional banks in relation with profit-loss sharing. }\end{array}$ & $\begin{array}{c}93 \\
(25.1 \%)\end{array}$ & $\begin{array}{c}49 \\
(13.2 \%)\end{array}$ & $\begin{array}{c}229 \\
(61.7 \%)\end{array}$ & 3.80 & 1.18 \\
\hline 5. & $\begin{array}{l}\text { There are areas of agreement in terms of transactions } \\
\text { between Islamic banks and conventional banks with } \\
\text { respect to profit-loss sharing. }\end{array}$ & $\begin{array}{c}92 \\
(24.8 \%)\end{array}$ & $\begin{array}{c}59 \\
(15.9 \%)\end{array}$ & $\begin{array}{c}220 \\
(59.3 \%)\end{array}$ & 3.71 & 0.86 \\
\hline
\end{tabular}

In addition, the majority of the respondents (121 or $71.6 \%$ ) agreed that Islamic banks based profit-loss sharing on joint business partnerships not on utilization of loan for financing the business of their customers like 
conventional banks in relation with profit-loss sharing. ( $M=3.80$; STD =1.18); $28(16.6 \%)$ disagreed with the statement while $20(11.8 \%)$ were neutral in this regard.

The respondents ( 122 or $86.3 \%$ ) agreed that there are areas of agreement in terms of transactions between Islamic banks and conventional banks with respect to profit-loss sharing. ( $M=3.71$; STD $=0.86) ; 9(20 \%)$; $71(5.4 \%)$ disagreed with this while $48(28.4 \%)$ were neutral with this. Table 3 shows responses on ProfitLoss Sharing (PLS).

\section{DISCUSSION}

This part presents the finding of this study. The overall findings of this paper are in keeping with several studies (Ahmed, 1999; Ahmad, 2006; Ahmad, 2007) that posit that there are banks' controls from different Muslim countries such as Malaysia (Siti Faridah, 2009) and Saudi Arabia (Alshamrani, 2014) and Bangladesh (Ahmed, 1999).

Similarly, it is noteworthy to say that, regulatory and supervisory mechanisms have great impact on profit sharing investment in Islamic finance. In addition, study by Archer and Karim (2009) argued that there are problems associated with profit sharing investment; however, there are likely solutions such as using Shari'ah principles to guide the regulatory framework of Islamic banks in Muslim countries (Archer and Karim, 2009; Siti Faridah, 2009). Though, Ayub (2007) suggests that proper understanding of modus operandi of Islamic finance is an ultimate requirement for laying solid foundation for regulatory framework which is in line with the proposition of many other studies (Archer and Karim, 2009). In other words, literature argues that operation of Islamic micro-financial institutions should be built on contractual agreement between the financial institution and the clients.

Furthermore, it is not contestable to posit that literature has acknowledged the effort of Malaysia as one of the uses Shariah as a benchmark to determine the practice of Islamic banking sector (Mahmoud, 2006). Many promoters of Islamic banking in Muslim countries have considered Islamic banks as operating interestfree banking system; nonetheless, studies such as Chong and Lin (2009) comparatively argues that does Islamic bank really interest-free or interest-based. In spite of rhetoric assertion by Chong and Lin (2009); many studies have responded to this which the present study has further buttressed that interest-free banking is an essential indicator in determining standard regulatory framework by Islamic banking system.

It is not arguable to say that, with different factors examined in this study, it can be asserted that Islamic banks provides standard regulatory framework; however, diversity and peculiarity of implementing multifarious factors is considered as a strength of this paper. This position has been demonstrated further by the study of El-Hawary, Grais and lqbal (2007). In addition, literature contends that there is efficiency in Islamic banks (Dewi, Sulaiman and Ferdian, 2010; Mondher, 2013) in various countries of Organization of Islamic Conference (OIC) such as: Bangladesh, Malaysia and Saudi Arabia. Moreover, studies have posited that contemporary Islamic finance provides innovative ideas on the applications and practice of Islamic financial services in the Muslim countries (Mahmoud, 2006; El-Hawary, Grais \& Iqbal, 2007).

\section{CONCLUSION}

This paper has empirically assessed three underlining dimensions -Operation of Islamic banking (OIB), Bank Control Law (BCL); Profit-Loss Sharing (PLS)-of regulatory framework in the context of Bangladesh. The paper has traced the historical antecedent of Islamic banking and finance in the country. The findings have 
demonstrated that the majority of the respondents were promoters of Islamic and it has been shown that they agreed the operation of Islamic banking should be based on public interest. It is further indicated that separate Act regulates the activities of Islamic banking as integral part of bank control law in the country. The paper also reiterated that, indirect monetary policy helps to fix profit and sharing ratios. In conclusion, the effective and efficient provision of a framework for standard regulation would promote Islamic banking system in selected three countries in particular and in the Muslim countries in general.

Thus, the following recommendations are made:

1. The country should expand the scope of regulatory framework by exploring the regulatory framework being provided in countries like Saudi Arabia and Malaysia in order to effectively standardise it.

2. The provision of standard framework for the operation of Islamic banking system is expected to be Shar'iah-Compliant must be constantly reviewed in order to show best practices specifically in demonstrating viability of Islamic banking system across the Muslim countries.

3. That the operation of Islamic banking should not only serve the public interest but it should take Shari'ah compliance into consideration.

The scope of Islamic baking as a multipurpose institution should be practically function in order to encourage novice and veteran pertaining to the effective functionality of Islamic banking.

\section{REFERENCES}

Ahmad, A.U.F. and Kabir, M.H. (2007). Regulatory and Performance of Islamic Banking in Bangladesh. Thunderbird International Business Review, vol. 49, 251-277. https://doi.org/10.1002/tie.20142

Ahmad, A. U. F. (2001). Problems of Islamic banking in Bangladesh. Paper presented to the Islamic Economics Research Bureau, Dhaka, Bangladesh.

Ahmad, A. U. F. (2004). Islamic banking in Bangladesh: Legal and regulatory issues. Paper presented at the Sixth Harvard University Forum on Islamic Finance, Cambridge, MA.

Ahmad, A. U. F. (2006). Legislations and issues on Islamic banking in Bangladesh. Presented at the First International Forum on Islamic Economics, Finance and Business for Young Scholars, Langkawi, Malaysia.

Ahmed, M. F. (1999). Islamic Bangladesh Limited: A profile. Seminar on Experiences in Islamic Banking. Islamabad, Pakistan: Institute of Policy Studies.

Archer, A., Karim, R.A.A. and Sundararajan, V. (2010). 'Supervisory, regulatory, and capital adequacy implications of profit-sharing investment accounts in Islamic finance', Journal of Islamic Accounting and Business Research, 1(1), pp. 10-31. https://doi.org/10.4135/9788132107675.n8

Archer, S and Karim, R.A.A. (2009) 'Profit-sharing investment accounts in Islamic banks: Regulatory problems and possible solutions', Journal of Banking Regulation, 10(4), pp. 300-306. https://doi.org/10.1057/jbr.2009.9

Ayub, M. (2007). Understanding Islamic Finance, John Wiley \& Sons, Ltd, UK, 2007, p. 241.

Chienwattanasook, K. \& Jermsittiparsert, K. (2019). Factors Affecting Job Stress among Employees in the Banking Sector of Malaysia. International Journal of Innovation, Creativity and Change, 6(2), 288-302.

Chong, B.S. and Liu, M.H. (2009) 'Islamic banking: Interest-free or interest-based?', Pacific- Basin Finance Journal, 17(1), pp. 125-144. https://doi.org/10.1016/j.pacfin.2007.12.003

Dar, H. (2011b). Importance of Shari'a audit for conventional banks offering Islamic financial products, Business Asia Weekly, 1 (42), pp.11. 
Dewi, M, K., Sulaiman, M and Ferdian, I.R (2010). 'Efficiency of Islamic banks in selected member countries of the Organization of Islamic Conference', International Journal of Monetary Economics and Finance, 3(2), pp.177-205. https://doi.org/10.1504/ijmef.2010.031236

El-Hawary, D., Grais, W. and lqbal, Z (2007). 'Diversity in the regulation of Islamic Financial Institutions', The Quarterly Review of Economics and Finance, 46, 778-800. https://doi.org/10.1016/..gref.2006.08.010

Godino, J. D., Rivas, H., Burgos, M., \& Wilhelmi, M. R. (2019). Analysis of Didactical Trajectories in Teaching and Learning Mathematics: Overcoming Extreme Objectivist and Constructivist Positions. International Electronic Journal of Mathematics Education, 14(1), 147-161. https://doi.org/10.12973/iejme/3983

Issaliyeva, A., Ospanova, A. N., \& Alibekul, A. (2018). Kazakhstan and GCC: Islamic component in joint collaboration. Opción, 34(85-2), 205-220.

Joemsittiprasert, W., Siriattakul, P., \& Jermsittiparsert, K. (2019). The Effect of Trust, Comitment, and SalesPerson Ethical Behavior on Customer Retention: The Mediating Role of Customer Satisfaction: Banking Industry of Thailand. International Journal of Psychosocial Rehabilitation, 23(4), 808-821. https://doi.org/10.37200/ijpr/v23i4/pr190411

Mahmoud A. E. (2006). Islamic Finance Law, Economics, and Practice, Cambridge University Press, New York, p. 86.

Mondher Bellalah, (2013). Islamic Banking and Finance, Cambridge Scholars Publishing, UK, pp. 58-59.

Obaidullah, M. (2005). Islamic Financial Services, Scientific Publishing Centre, King Abdulaziz University, Jeddah, Saudi Arabia, p. 184.

Simon, A. and Rifaat A. K. (2007). Islamic Finance: the Regulatory Challenge, John Wiley \& Sons: Singapore, p. 127.

Siti Faridah, H.A.J. (2009). 'Sharia-compliant financial instruments: principles and practice', Company Lawyer, Vol. 30, issue 1, 2009, p. 176.

Smolo, Edib, and Abdul Ghafar Ismail. (2011). A Theory and Contractual Framework of Islamic Microfinancial Institutions' Operations. Journal of Financial Services Marketing, 15.4, 287-295. https://doi.org/10.1057/fsm.2010.24

\section{(@) $(\Theta \Theta \Theta$}

This work is licensed under a Attribution-NonCommercial-NoDerivatives 4.0 International (CC BY-NC-ND 4.0). 